\title{
REPENSAR MORAL DA EUCARISTIA COM FOCO NA UNIDADE MUNDIAL ENTRE CATÓLICOS E LUTERANOS
}

\author{
SILVA, Itamar Marques da ${ }^{1}$ \\ "Deixai as crianças e não as impeçais de vir a mim, \\ pois delas é o Reino dos Céus" (Mt. 19:14)
}

\begin{abstract}
RESUMO
Certa vez Jesus disse: "Deixai as crianças e não as impeçais de vir a mim, pois delas é o Reino dos Céus" Mt. 19:14. O presente versículo continua sendo a voz de Jesus ecoando aos seus discípulos para não impedir ninguém de chegar até Ele. Esta é uma repreensão à falsa moral que os discípulos usavam. A moral cristã se pauta no amor, relação, acolhimento e reconhecimento de Deus no próximo. No início da idade moderna, muito se discutiu sobre a presença real de Cristo na Eucaristia, tanto que a partir daí o Concílio de Trento reafirmou o quarto concílio de Latrão que, pela consagração dos elementos acontece a conversão dos mesmos no corpo e sangue de Cristo. Todavia em meio à pluralidade de interpretações cada segmento cristão aderiu à doutrina que mais lhes fazia sentido. A pequena diferença do pensamento luterano ao católico sobre essa doutrina é um convite ao repensar a promoção da já discutida Hospitalidade Eucarística.
\end{abstract}

Palavras-chave: Catolicismo. Ecumenismo. Luteranismo. Cristianismo. Eucaristia.

\begin{abstract}
Jesus once said, "Let the little children come to me, and do not hinder them, for the kingdom of heaven belongs to such as these ${ }^{2 "}$ (Mt 19:14). This verse continues to be the voice of Jesus echoing to his disciples so as not to prevent anyone from reaching him. This is a rebuke to the false morals that the disciples used. Christian morality is based on the love, relationship, acceptance and acknowledgment of God in the neighbor. At the beginning of the modern age there was a great deal of discussion about the real presence of Christ in the Eucharist, so much so that from this point onwards the Council of Trent reaffirmed the fourth council of the Latrão that by the consecration of the elements the conversion of the elements takes place in the body and blood of Christ. However, during a plurality of interpretations, each Christian segment adhered to the doctrine that made most sense to them. The small difference of Lutheran thought to the Catholic on this doctrine is an invitation to rethink the promotion of the already discussed Eucharistic hospitality.
\end{abstract}

Key-words: Catholicism. Ecumenism. Lutheranism. Christianity. Eucharist.

\footnotetext{
${ }^{1}$ Aluno do curso de bacharelado em Teologia da PUC-PR. Graduado em História (Licenciatura) pelo Centro Universitário Internacional e pós graduado em metodologia do ensino de história pelo Centro Universitário Internacional.

2 Cf. New International Version (NIV) Holy Bible, New International Version $\AA^{\circledR}$, NIV® Copyright @ $1973,1978,1984,2011$ by Biblica, Inc.® Used by permission. All rights reserved worldwide.
} 


\section{INTRODUÇÃo}

O presente trabalho não busca fazer qualquer questionamento doutrinal às instituições cristãs, as quais carregam em si as mais belas reminiscências da tradição cristã. Também não busca por meio deste oferecer uma solução concreta e portando definitiva, mas pretende de maneira respeitosa às diferenças, compreender por meio da moral cristã sobre um repensar da Eucaristia como um sacramento oferecido a todos os cristãos.

É notável a evolução no final século XX, e sobretudo no século XXI, no que diz respeito à aproximação entre luteranos e católicos. "Sabemos que todas as coisas trabalham juntas para o bem daqueles que amam a Deus, daqueles a quem Ele chamou de acordo com o seu plano" (Romanos 8:28). O reencontro de cristãos luteranos e católicos, tem se dado devido ao esforço de ambas as partes diante da perspectiva ecumênica. Dentre os avanços nessa aproximação, observa-se, a criação da Comissão Internacional Católico-Luterana - CICL, peregrinações, celebrações ecumênicas, a assinatura da declaração conjunta de reconciliação entre a Federação Luterana Mundial e a Igreja Católica na data em que a Reforma Protestante completava 500 anos, há também compartilhamento de templos pelo mundo, entre outros sinais de aproximação. Todavia, o maior sinal ainda não aconteceu. Celebrar a comunhão juntos é o maior sinal, porém, esta é uma ferida que ainda não foi curada, nem entre os segmentos luteranos, que dirá a celebração em conjunto. Todavia, sabese que um importante passo nesse sentido já foi dado através da Declaração sobre Hospitalidade Eucarística ${ }^{3}$ em 1973.

Católicos e luteranos têm mais em comum do que divergências quando se trata da eucaristia, pois ambos acreditam na presença real de Cristo nos elementos da Eucaristia. Também concordam que o sacramento pode ser servido em duas ou uma espécie, como o próprio Lutero disse em um sermão em 1519 antes de fazer sua breve confissão sobre o sacramento ${ }^{4}$,

Tenho para mim, entretanto, que seria bom que a Igreja, num concílio geral, tornasse a determinar que ambas as espécies fossem dadas a todas as pessoas, assim como aos sacerdotes. Não porque uma espécie não seja já o suficiente, pois o desejo da fé certamente já basta. Assim diz Santo Agostinho: "Para que ficas preparando a barriga e os dentes? Crê somente, e já desfrutaste o sacramento." (LUTERO, Obras Selecionadas Vol. 1, pág.428)

É notável que há uma grande aproximação entre o pensamento luterano e o católico sobre a Eucaristia, todavia a grande questão não está na maneira como ambas entendem o sacramento, mas na atitude moralista que as mesmas impõem sobre quem pode participar.

${ }^{3}$ Documento da Comissão Internacional Católico-Luterana.

${ }^{4}$ Kurzes Bekenntnis vom heiligen Sakrament, WA 54, 141-67 
Tanto na tradição católica romana quanto na tradição luterana há barreiras para os cristãos participarem da mesa do Senhor. São barreiras morais impostas pelas instituições no decorrer da história. Estas, privam os cristãos de terem a comunhão com Cristo e com os próprios irmãos. Tal privação se dá primeiramente pela tentativa de institucionalizar Cristo, impor regras morais a partir da interpretação de uma falsa imagem de Deus.

\title{
2. A MORAL CRISTÃ FUNDAMENTAL
}

A frase: "deixai que as criancinhas venham a mim", é a resposta de Jesus a uma falsa moral aplicada pelos seus discípulos que acreditavam que alguns (as crianças) teriam que ficar longe do mestre para não o atrapalhar.

A moral fundamental ${ }^{5}$ cristã não se apresenta como um conjunto de regras que se infringidas resultam em consequências pessoais para o cristão, mas a moral cristã fundamental é moldada em uma relação de amor. O cristão não faz algo porque lhe é imposto, mas porque ele se deixa tocar pelo amor. Assim, a moral cristã não tem uma função de impor para julgar, mas de dispor em amor e acolhimento para transformar o velho homem e revelar nele e por ele o Deus que é unicamente amor.

A moral cristã não obriga ninguém a amar, mas o cristão ama por ser amado e por conhecer a Deus e deixa-lo revelar-se em si. Conforme I João 4:8-12:

\begin{abstract}
Aquele que não ama não conheceu a Deus, porque Deus é Amor. Nisto se manifestou o amor de Deus por nós: Deus enviou o seu Filho único ao mundo para que vivamos por ele. Nisto consiste o amor: não fomos nós que amamos a Deus, mas foi ele quem nos amou e enviou seu Filho como vítima de expiação pelos nossos pecados. Amados, se Deus assim nos amou, devemos, nós também, amar-nos uns aos outros. Ninguém jamais contemplou a Deus. Se nos amarmos uns aos outros, Deus permanece em nós, e o seu Amor em nós é realizado.
\end{abstract}

Em seus mais de 2.000 anos de história o cristianismo enfrentou interpretações equivocadas da moral cristã, entre elas as falsas imagens de Deus, apresentando um Deus vingativo, descomprometido com a história humana ou um Deus "heterônomo" que usurpa a liberdade com que dotou a criatura racional. Segundo Vidal,

Essa tem sido a compreensão de Deus como legislador universal que ao criar o mundo, ordena-o segundo uma "lei eterna", a qual vai dando a conhecer por diversos caminhos e procedimentos.

Sobre essa compreensão de Deus como uma vontade heterônoma à pessoa, apoiaram-se a maior parte das falsificações da moral cristã: o voluntarismo nominalista; o fundamentalismo bíblico; o legalismo tanto eclesiástico como civil e o naturalismo objetivista. (VIDAL, 2000, p. 28).

5 Moral Fundamental cristã tem seus fundamentos nos ensinamentos de amor e justiça propostos por Jesus. A moral fundamental cristã é a base norteadora do Reino. 
Tais interpretações equivocadas de Deus trouxeram sistemas moralistas para o cristianismo, os quais não se enquadravam na mensagem cristã do amor. Hoje, o cristianismo em partes já superou o Jansenismo e a moral casuística ${ }^{6}$, já não se vive em totalidade a relação de simonia ${ }^{7}$ ou níveis de penas para tipos de "delitos". A moral casuística alimentou eventos de atrocidades ao ser humano como a Inquisição. Na atualidade, essa "falsa moral" não divide mais cristãos de judeus, mas cristãos de cristãos e o próprio corpo do Senhor.

A moral cristã é pautada no acolhimento e no amor regenerador. Todo verdadeiro cristão vive unicamente em amor na relação com o próximo onde encontra-se Deus, pois Cristo disse que "cada vez que o fizestes a um desses meus irmãos mais pequeninos, a mim o fizestes"8.

Partindo da moral fundamental cristã, a qual propõe o acolhimento, percebe-se que a comunhão entre cristãos é essencial. Desta forma, evidencia que o sacrifício de Cristo, isto é, o seu corpo em totalidade oferecido para a humanidade, não deve ser restringido por "preceitos morais" pautados na casuística. O corpo de Cristo foi por Ele oferecido e dado à humanidade em função do Reino.

Assim como os discípulos tentavam impedir as crianças de chegarem ao Mestre ${ }^{9}$, assim também os atuais discípulos cerceiam aqueles que querem chegar a Cristo, de participar do banquete que o próprio Cristo ofereceu a todos.

Luteranos e católicos vivem divididos pelo peso de uma falsa moral que caminhou nos dois grupos ${ }^{10}$ por quase 500 anos. O reencontrar-se na mesa do Senhor pode ser a liberdade à moral fundamental cristã, isto é, o amor.

\section{COMPREENSÃO DA EUCARISTIA}

Compreende-se Eucaristia ${ }^{11}$ como sinal da unidade do povo de Deus ${ }^{12}$; não da divisão, como vínculo da caridade; não da rejeição, como o banquete pascal no qual se recebe Cristo.

\footnotetext{
${ }^{6}$ Moral pautada em um manual de relação pecado versus pena.

${ }^{7}$ Compra de perdão.

8 Mateus 25, 40

${ }^{9}$ Cf. Mt 19,13.

10 O Concílio Vaticano II, no decreto Unitatis Redintegratio, afirmou: "Comunidades não pequenas separaram-se da plena comunhão da Igreja Católica, algumas vezes não sem culpa dos homens de um e doutro lado" (n. 3). Em 1970, a Federação Luterana Mundial também pediu perdão pelas "distorções polêmicas" presentes no pensamento dos reformadores.

${ }_{11}$ Cf. Dicionário crítico de teologia: Jean-Yves Lacoste, p. 679: Eucaristia é o mesmo que ação de graças, provém de Lc 22,19 e 1 Cor 11,24. "Ceia do Senhor" 1 Cor 11,20, o termo é sinônimo de partilha em At. 2,42.

${ }^{12} \mathrm{Cf}$. CIC 1324
} 
“Tomai e comei, isto é meu corpo. Depois, tomou um cálice e, dando graças, deu-o a eles, dizendo: Bebei dele todos, pois isto é o meu sangue, o sangue da Aliança ${ }^{13}$, que é derramado por muitos para remissão de pecados". (Mt 26:26-28)

As palavras de Jesus ao instituir a Eucaristia, expressam a participação no seu corpo como um continuum ao sacramento do batismo, pois, no batismo o ser humano é regenerado, porém sua regeneração não Ihe priva de sua liberdade. Portanto a Eucaristia tem a função de perdoar os pecados ${ }^{14}$ e manter o ser humano em sua comunhão com Cristo. Batismo e Eucaristia são os dois sacramentos indissociáveis desde a cruz até o cristianismo atual.

Com sua páscoa, Cristo abriu a todos os homens as fontes do Batismo. Com efeito, já havia falado da paixão que iria sofrer em Jerusalém como de um "batismo", com o qual devia ser batizado. ${ }^{15} \mathrm{O}$ sangue e a água que escorreram do lado traspassado de Jesus crucificado ${ }^{16}$ são sinais do Batismo e da Eucaristia, sacramentos da vida nova: ${ }^{17}$ desde então é possível "nascer da água e do Espírito" para entrar no reino de Deus. (CIC. 1225).

A comunhão da vida divina e a unidade dos cristãos na Terra são expressas e realizadas pela Eucaristia, sendo ela uma amostra antecipada da plenitude para a igreja militante ${ }^{18}$. Ela oferece a manutenção da fé por meio do perdão de pecados.

\begin{abstract}
A Santa Ceia oferece, em comum como o santo Batismo e a absolvição particular (Privatabsolution), a remissão dos pecados, vida e salvação aos pecadores individualmente. Assim a mesma graça que o Evangelho proclama a todos é anunciada e oferecida pessoalmente a cada um que frequenta a mesa do Senhor. (MUELLER, 2004, p.477)
\end{abstract}

Evidentemente que pautado na moral casuística não é possível julgar quem é digno ou indigno de participar do corpo do Senhor. Na visão de Lutero, o indigno é aquele que não crê no mistério de que Cristo ofereceu seu corpo em prol e para remissão de pecados ${ }^{19}$. A Bíblia de Jerusalém em sua nota de rodapé em referência ao texto de 1 Cor 11:27, faz uma referência à moral fundamental cristã, afirmando que os indignos são aqueles que não estão unidos no amor, estes estão na categoria daqueles que mataram Jesus ${ }^{20}$. Daí compreende-

\footnotetext{
${ }^{13}$ Lutero traduz a expressão diatheke como testamento (e não aliança) Cf. NESTIGEN, James Arne. "Zurique e Genebra: a Polêmica da Presença no Contexto da Reforma" In: BUSS, Paulo Wille. Comunhão e separação no altar do Senhor: $2^{\circ}$ simpósio internacional.

${ }^{14}$ Tomás de Aquino ao falar sobre os efeitos da eucaristia (Summa Theologiae IIla. Pars Qs. 79-80 - Sermão sobre o Corpo do Senhor) também afirma que: "O Sacramento da Eucaristia pode também perdoar toda a pena devida ao pecado. Este efeito pode ocorrer tanto por ele ser sacrifício, como por ser sacramento. A Eucaristia possui razão de sacrifício na medida em que é oferecido; possui razão de sacramento na medida em que é tomado."

${ }_{15}$ Cf. Mc 10,38; Lc 12,50.

${ }^{16} \mathrm{Cf}$. Jo 19,34 .

17 Cf. 1 Jo $5,6-8$.

${ }^{18}$ Cf. CIC 1326; 1 Cor 15,28.

${ }^{19} \mathrm{Cf}$. Catecismo menor V, 9-10.

${ }^{20}$ Cf. Dt 19,10; Hb 6,4-6, 10,29.
} 
se 1 Jo 4:8; pois, se não tiver amor, não se conhece Deus, desconhecendo Deus é impossível crer no mistério do corpo de Cristo. Assim, a moral fundamental e a eucaristia estão intimamente ligadas.

\subsection{EUCARISTIA E MORAL}

Ao recorrer à escritura sagrada e à patrística, percebe-se que não há uma regra moral para impedir que alguém seja privado da comunhão com Cristo e com a comunidade. $\mathrm{O}$ primeiro catecismo dos cristãos já fazia um convite para que todos, exceto os não batizados em nome do Senhor, participassem da Eucaristia. Conforme a Didaqué,

Do mesmo modo como este pão partido tinha sobre as colinas, e depois recolhido para se tornar um, assim também a tua Igreja seja reunida desde os confins da terra no teu reino, porque tua é a glória e o poder, por meio de Jesus Cristo, para sempre. (Didaqué IX.4)

É notável que a realidade atual do cristianismo é composta por vários grãos de trigo espalhados pela grande seara de Cristo, mas conforme as palavras do próprio Cristo reveladas em João 10:16, "Tenho ainda ovelhas que não são deste redil: devo conduzi-las também; elas ouvirão a minha voz; então haverá um só rebanho, um só pastor". A igreja, enquanto militante, faz parte desse projeto de Cristo de unir as ovelhas em comunhão com o Cristo e não de segrega-las institucionalmente, privando a realização do Reino que: Já é, e ainda não ${ }^{21}$.

A comunhão não diz respeito a mesclar diferenças, mas em manter quando necessário, pois "nem todos os dedos da mão são iguais, todavia fazem parte de um mesmo corpo 22". A comunhão se remete à essência, e nela todos os cristãos são, ou pelo menos deveriam ser iguais, a essência é Cristo. Daí, entende-se a comum-união, sendo a essência unificadora dos cristãos enquanto peregrinos rumo à terra prometida.

A questão da mesa eucarística é um assunto polêmico, mas se reascende constantemente na história. As igrejas de tradições luteranas têm em comum a teologia de Lutero e a compreensão da presença real de Cristo na ceia. "Da ceia do Senhor ensinam que o corpo e o sangue de Cristo estão verdadeiramente presentes e são distribuídos aos que comungam na ceia do Senhor" (Confissão de Augsburgo X.1). Todavia as atuais igrejas luteranas se mantêm divididas na mesa do Senhor por questões institucionais. Isso é notável principalmente no Brasil, onde estão presentes as duas maiores igrejas luteranas do mundo, as quais se mantêm divididas no altar do Senhor.

${ }^{21}$ Frase do teólogo luterano Oscar Culmamm

${ }^{22}$ Expressão utilizada em I Cor. 12, para explicar a diversidade de dons espirituais. 
Recentemente ocorreu um evento significante no meio luterano. No dia 26 de setembro de 2018, o Concílio Internacional Luterano que ainda se mantém distanciado do diálogo ecumênico, recebeu em sua membresia 17 corpos eclesiásticos, representando aproximadamente 4,15 milhões de luteranos mundialmente. Essa adição mais que duplica o número de luteranos associados ao ILC ${ }^{23}$ ao redor do mundo, trazendo o total a aproximadamente 7,15 milhões de membros. A votação para aceitação das igrejas como novos membros ocorreu nos dias 25-26 de setembro na cidade de Antuérpia, Bélgica, durante a Conferência Mundial do ILC de 2018. No total, o ILC recebeu 10 novas igrejas da África, 3 da Europa, e 4 da Ásia (incluindo a Sri Lanka's Ceylon Lutheran Church, que sucede a agora extinta Lanka Lutheran Church). Isso leva o total de igrejas associadas ao ILC para 54. De todas as novas igrejas em membresia com o ILC, 11 foram recebidas como membros completos, e 6 como membros em observação. A membresia foi negada a duas igrejas nessa conferência. A comunhão aberta entre todos os luteranos no mundo, bem como a reconciliação entre luteranos e católicos é um clamor de Cristo. Especialmente ao significativo número dos membros do ILC que ainda se mantêm afastados da relação com os demais cristãos luteranos e católicos no mundo.

\subsection{A EUCARISTIA EM LUTERO}

Lutero compreende a Eucaristia com quase a mesma ortodoxia compreendida pela "igreja católica24". A diferença nas compreensões se dá no uso do termo aristotélico transubstanciação ${ }^{25}$, implementado por Tomás de Aquino, o qual Lutero não concordou ${ }^{26}$. Em um segundo momento, Lutero defendia a celebração eucarística como algo comum entre leigos e sacerdotes, servindo assim o sacramento em duas espécies para todos ${ }^{27}$.

O teólogo alemão defende com bastante ênfase a questão de que todos possam participar da mesa do Senhor, conforme abaixo,

${ }^{23}$ Sigla americana do Concílio Internacional Luterano.

${ }^{24} \mathrm{Cf}$. CIC 830. Embora a expressão "igreja católica" não seja muito adequada para se referir a igreja de Cristo com sede em Roma, a expressão se ressignificou na história e assumiu uma característica denominacional, daí usar-se-á a expressão para referir-se a instituição cristã com sede em Roma. Os documentos luteranos em sua maioria utilizam a expressão igreja católica para referir-se a igreja cristã.

${ }^{25}$ No artigo: O problema da transubstanciação, de 1964, Joseph Ratzinger explicou de tal maneira a conversão do pão e do vinho no corpo e sangue de Jesus que disse que, vista daquela forma, não haveria oposição entre a interpretação católica e a luterana.

${ }^{26}$ Lutero como especialista em Antigo Testamento faz uma leitura semítica do corpo de Cristo, mas não nega a presença real de Cristo nos elementos eucarísticos.

27 Lutero propunha por meio disso a moral fundamental cristã. No Reino não há sistemas hierárquicos com privilégios. 
... em seu famoso tratado de 1520, Do Cativeiro Babilônico da Igreja. Nessa obra, o professor da Universidade de Wittenberg citou um trecho do Pai da Igreja Cipriano que mencionava que o cálice da Eucaristia foi dado a uma menina. Para Lutero isto provava que, contra a usança Católica Romana da época do reformador, na antiga Igreja ambas as espécies da comunhão eram oferecidas aos leigos, até as crianças. (COLES, 2009, p.98) ${ }^{28}$

Sobre a defesa do uso dos dois elementos, Lutero defende uma igualdade social entre sacerdotes e o povo, sendo todos iguais perante Cristo. Para Lutero o problema não está na questão de que na presença de um só elemento a mesa do Senhor estaria incompleta, pois em seu "Sermão sobre o Venerabilíssimo Sacramento do Santo e Verdadeiro Corpo de Cristo e sobre as Irmandades", de 1590, Lutero afirma que:

Não porque uma única espécie não seja já suficiente, pois o desejo da fé certamente já basta. Assim diz Santo Agostinho: "Para que ficas preparando a barriga e os dentes? Crê somente, e já desfrutaste o sacramento." (Lutero, 1519, OS I p.428).

Na questão do termo aristotélico implantado por Tomás de Aquino, Lutero foi bem cauteloso, pois o que ele sugeriu foi que as palavras da Instituição não fossem adulteradas por termos filosóficos, mas que mantivessem o texto bíblico ${ }^{29}$. Mesmo que Lutero não tenha abolido totalmente as relações entre conceitos filosóficos e o cristianismo, ele fez críticas a algumas heranças helenistas, entre elas, a missa como sacrifício ${ }^{30}$, pois para ele o sacrifício foi exclusivamente um único e irrepetível na economia da salvação. O que se celebra na eucaristia é a memória do Cristo ressuscitado. A questão da Eucarística por algum tempo foi compreendida como sacrifício pois,

Durante seu desenvolvimento, a Eucaristia foi compreendida como sacrifício. Todavia, quando ela é chamada de Ouoía [sacrifício] em Did $14.1^{31}$, isto ainda ocorre em sentido figurado ou isso serve apenas para denominar a Eucaristia de ato cúltico que, na comunidade cristã, veio em substituição dos sacrifícios no sentido próprio. Também Inácio ${ }^{32}$ recorre à terminologia do sacrifício quando, em admoestações à unidade da comunidade reunida sob o bispo, fala do Guoıaotńpıov (altar ou recinto do altaro, dentro do qual é oferecido o

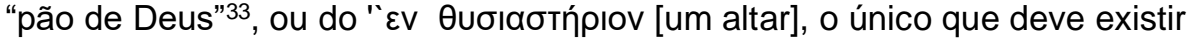
na comunidade ${ }^{34}$. (BULTMANN, 2008, p.202)

${ }^{28}$ COLES, David. "O Princípio Escriturístico de Lutero na Polêmica sobre a Santa Ceia" In: BUSS, Paulo Wille. Comunhão e separação no altar do Senhor: $2^{\circ}$ simpósio internacional de Lutero. Porto Alegre: Concórdia, 2009.

${ }^{29}$ Cf. 1 Cor $11,24-25$.

30 Cf. BULTMANN, Rudolf. "Teologia do Novo Testamento" 2008, p.203.

${ }^{31}$ Cf. Didaqué XIV, 1: Reúnam-se no dia do Senhor para partir o pão e agradecer, depois de ter confessado os pecados, para que o sacrifício de vocês seja puro.

32 Inácio de Antioquia

${ }^{33} \mathrm{Cf}$. Inácio à Efésios 5,2.

${ }^{34} \mathrm{Cf}$. Inácio à Filadelfia 4. 
As maiores controvérsias eucarísticas de Lutero, ao contrário do que muitos imaginam, se deram contra os reformadores, os quais Lutero por vezes classificou como sectários. Os maiores embates se deram com Zwínglio o qual negava a presença real do corpo e sangue de Cristo no sacramento por meio de sua doutrina alloeosis. Lutero também discordou das idéias calvinistas.

Lutero enfatiza a presença real de corpo e sangue de Cristo nos elementos. Em 1520 ao escrever o Tratado "Da Ceia de Cristo", Lutero responde de maneira ríspida mas coesa, aos demais reformadores que negavam a presença real de Cristo nos elementos: "Antes de optar pelo puro sangue com os fanáticos, iria preferir o puro sangue com o papa". (Lutero, OS IV, 336). É evidente que não há grandes barreiras doutrinárias entre luteranos e católicos acerca da mesa do Senhor. Assim, os milagres eucarísticos são respeitados tanto no ambiente católico quanto no ambiente luterano.

Por que não deixar que o milagre da união também possa ocorrer pela partilha na mesa eucarística? A unidade dos cristãos junto à mesa do Senhor é mencionada por Lutero ao explicar o significado da Eucaristia. Para ele,

\begin{abstract}
O que este sacramento significa ou opera é a comunhão de todos os santos ${ }^{35}$. É por esta razão que se costuma chama-lo, na linguagem comum, de synaxis ou communio, isto é, comunhão; e communicare, em latim, significa receber essa comunhão, o que, no vernáculo, chamamos de zum sacrament gehen (ir ao sacramento). A razão disso é que Cristo forma um corpo espiritual com todos os santos, assim como o povo de uma cidade constitui uma comunidade e um corpo, sendo cada cidadão membro do outro e da cidade inteira. Da mesma maneira, todos os santos são membros de Cristo e da Igreja, que é uma cidade espiritual e eterna de Deus. (Lutero,1519, OS I, p.429)
\end{abstract}

Alguns avanços nesse sentido já foram dados, mas há ainda uma cidade dividida por muros, isto é, o corpo de Cristo dividido por uma moral não cristã.

\title{
3.3 AVANÇOS ECUMÊNICOS NA MESA DO SENHOR
}

A mesa do Senhor tem sido um lugar comum para receber os seguidores de Cristo no mundo, uma "Hospitalidade Eucarística" é de fundamental importância para os seguidores de Cristo que militam em amor, mas que precisam ser alimentados pelo "Pão da Vida" e por

\footnotetext{
35 Todos os santos. Lutero define o cristão sendo Simul iustus et peccatur "justo e pecador" sendo os santos verdadeiramente santos em Cristo, mas não se tornam insensíveis.Os santos em Cristo continuam pecando. Quando eles agem em conformidade a nova natureza, criada pelo Espírito Santo eles vivem em conformidade à vontade de Deus, o viver deles é santo. Eles seguem as recomendações dos apóstolos sendo servos uns dos outros através do amor. Assim os filhos de Deus suportam as fraquezas do próximo, perdoam-se mutuamente, procuram viver em concórdia e paz procurando evitar as desavenças e ajudam-se mutuamente.
} 
estarem em lugares distantes de suas casas, precisam alimentar-se na casa dos irmãos ao longo da peregrinação ${ }^{36}$ rumo à plenitude.

Neste sentido, os irmãos católicos e luteranos começam a abrir as portas de suas igrejas para hospedarem-se mutuamente, compartilhando dos mesmos espaços para realizarem cultos e missas. Todavia, há um anseio de ambas as partes em poderem se alimentar à mesa como hóspedes que têm um alimento comum.

No decreto Unitatis Redintegratio, o Vaticano II recomendou começar e continuar o diálogo ecumênico sobre os sacramentos (Unitatis Redintegratio 22). Ora, as declarações e relatórios sobre a Eucaristia, que já foram fruto das conversações bilaterais oficiais entre católicos e anglicanos ou luteranos, afirmaram uma fé eucarística comum, compatível com diferenças secundárias. (SHETH, 2006, p.916) ${ }^{37}$.

A água derramada do corpo de Cristo crucificado já é algo comum entre católicos e luteranos. Ambas as instituições reconhecem mutuamente o batismo cristão ${ }^{38}$. A partir disso, a declaração conjunta entre luteranos e $\operatorname{católicos}^{39}$ busca o reconhecimento do sangue derramado ${ }^{40}$ e corpo dado em favor da humanidade.

A Comissão Internacional Católico-Luterana - CICL tem feito um trabalho de unificação e compreensão das pequenas divergências. Segundo o Relatório de Malta, a Comissão Mista Internacional Católico-Luterana continuará atenta aos desafios e às oportunidades específicas que as duas Igrejas possam encontrar no cumprimento da Missão de Cristo no mundo, na esperança de que luteranos e católicos possam, ao enfrentá-los, apoiarem-se mutuamente, em escala sempre maior.

"O diálogo católico-luterano encontra-se hoje numa situação intermediária entre resultados já obtidos e os objetivos futuros. A comunhão plena está no futuro" (WOLFF, 2017, p. 182$)^{41}$.

A comunhão plena dar-se-á com efetivação da Hospitalidade Eucarística de ambas as denominações. Todavia, há uma barreira entre luteranos e católicos ainda a ser superada, pois é incoerente que uma falsa moral ainda os impeçam de celebrarem juntos à mesa do Senhor, efetivando o que foi proposto no documento da Hospitalidade Eucarística.

${ }^{36}$ Rf. Ex 15,22-18,27.

37 SHETH, Noel. "A Eucaristia em Contexto Ecumênico Reflexões de um Católico" In: BROUARD, Maurice. Eucharistia: Enciclopédia da eucaristia. 2ªed. São Paulo: Paulus,2007.

${ }^{38}$ Cf. Código de Direito Canônico, cânon 869;

39 Declaração sobre Hospitalidade Eucarística (1973)

40 Ou sangue da nova aliança, conforme: Giraldo, 2003, p.177.

${ }^{41}$ WOLFF, Elias. "O diálogo católico-luterano visto por um teólogo católico" In: ROCHA, Claudio Oliveira; Rocha, Alessandro Rodrigues. Ecumenismo e Reforma. São Paulo: Paulinas, 2017. 
Constatamos com alegria que no santo Batismo nós aceitamos uns aos outros como filhos e filhas do mesmo Pai e, portanto, como irmãos e irmãs. Somos incorporados em Cristo, por meio deste santo Sacramento. Mas é lamentável e escandaloso o fato de que na mesa do Senhor ainda estejamos divididos e não possamos ir juntos à mesma Santa Ceia.

A mesa é única e indivisível. Ela sempre está dada anteriormente à nossa construção da unidade e vai além das nossas diferenças doutrinais. (2o․ Seminário Bilateral IECLB - CNBB - 8-9/12/1998, p.1 $)^{42}$

São importantes avanços que a IECLB em parceria com a CNBB está dando. Todavia, há uma divisão entre grupos luteranos que precisa ser superada.

\subsubsection{Luteranos divididos}

Alguns segmentos luteranos de caráter confessional, aderiram um fechamento institucional com luteranos de outras instituições. Assim, atualmente no Brasil, as duas maiores instituições luteranas, IELB e IECLB seguem separadas ${ }^{43}$ no altar do Senhor. Além das denominações menores como as pertencentes ao sínodo de Wisconsin ${ }^{44}$ e também as do sínodo riograndense. Mesmo que todas compreendam a eucaristia com a mesma ortodoxia deixada por Lutero.

Partindo do pressuposto que todas, em especial as duas maiores ${ }^{45}$ concordam de maneira ipsis litteris com o pensamento de Lutero acerca da Eucaristia, não há motivos para não haver também a Hospitalidade Eucarística em ambas. Não importa se quem fizer a consagração dos elementos for um pastor ou uma pastora. Pois,

Pela função das palavras de Cristo na ação eucarística, esta se transforma em vasta anamnese, em memorial efetivo e em atualização. Essa anamnese é feita na ação sacramental da comunidade sob a direção de seu ministro ordenado. Todavia, o sujeito da ação anamnética da Eucaristia - e isto é decisivo - é Cristo ressuscitado presente em sua Palavra. (GASSMANN, 2006, p. 874) 46

Portanto, uma moral pautada em julgar os personagens ${ }^{47}$ que se tornam instrumentos de Deus, na condição de ministro a realizar a consagração, é uma moral anticristã, já que a moral fundamental cristã se dá em amor.

42 2ํ.Seminário Bilateral IECLB - CNBB - 8-9/12/1998 "Hospitalidade Eucarística" In: .Seminário sobre Hospitalidade Eucarística. Disponível em

<http://www.luteranos.com.br/conteudo/hospitalidade-eucaristica-1>. Acesso e: 20 set. 2018.

43 Há diversos segmentos luteranos no Brasil, porém as duas maiores instituições são IECLB e IELB.

${ }^{44}$ Estão em processo de evangelização no Brasil.

45 IELB e IECLB (Concílio Internacional Luterano e Confederação mundial luterana)

${ }^{46}$ GASSMANN, Günther, "Como a palavra de Deus tem seu desdobramento na ceia? (Igreja Luterana)" In: BROUARD, Maurice. Eucharistia: Enciclopédia da eucaristia. $2^{a}$ ed. São Paulo: Paulus, 2007

${ }^{47}$ Moral casuística, ex:. uma ministra não pode fazer a consagração dos elementos. 
Celebrar em conjunto com as diversas ramificações luteranas é compreender os ensinamentos de justiça social ensinados por Lutero ao defender a eucaristia sob duas espécies também aos leigos ${ }^{48}$.

\subsection{CORPO DE CRISTO COMO UNIFICADOR DA IGREJA MILITANTE PARA A} PLENITUDE

Cristo se ofereceu em função do Reino, sendo este composto pelo grande número dos marginalizados, impuros, rejeitados, entre outros. O próprio Jesus fez um convite especial para estes que estavam oprimidos pelo jugo da moral judaica, convidando-os a carregarem o jugo leve e o suave fardo 49

Jesus deixou bem claro que veio em função dos doentes ${ }^{50}$, dos famintos e sedentos. Sua função é trazer vida em abundância ${ }^{51}$, sendo Ele o próprio alimento, um novo maná, o pão da vida ${ }^{52}$. Sendo Ele a água que sacia a sede ${ }^{53}$, o vinho que traz a alegria ${ }^{54}$. Todo aquele que está nele e participa d'Ele é sarado, e "Na Eucaristia nós partimos o único pão que é remédio de imortalidade, antídoto para não morrer, mas para viver em Jesus Cristo para sempre". (Inácio de Antioquia. apud. CIC. 1405).

O corpo de Cristo é partilhado ao redor de uma mesa, não pode ser confundido com alimento delivery fast-food, mas compreende-se um único corpo partilhado por todos em memória do seu sacrifício por todos. Desta forma, a Eucaristia é a responsabilidade pelo outro, é a memória do ressuscitado que quer revelar ao humano o oculto. Daí, se compreende a expressão: "Eis o mistério da fé", pois a Eucaristia é a fonte libertadora de Cristo no humano.

A história da salvação compreende um único corpo oferecido por amor a toda humanidade. Separar pessoas de participar do único corpo por meios de uma moral casuística é impedir a realização do reino que já está entre nós, todavia, não em sua plenitude. O único corpo de Cristo tem função unificadora entre os cristãos, assim, em Cristo somos um. "Já que há um único pão, nós, embora muitos, somos um só corpo, visto que todos participamos desse único pão". É compreensível que a unidade da plenitude clama por manifestar nessa igreja militante, que embora siga dividida no partilhar do corpo do Senhor, anseia pela plenitude e muitas vezes profere a oração do Apocalipse: "vem Senhor Jesus ${ }^{55 "}$. Todavia, é preciso que

48 Cf. OS 1, p. 428.

49 Cf. Mt 11, 28-30.

50 Cf. Mc 2,17; Mt 9,12.

51 Cf. Jo 10,10 .

52 Cf. Jo 6,35.

53 Cf. Jo 4,14

${ }^{54}$ Cf. Jo 2,4-10.

${ }^{55}$ Cf. Ap 22,20. 
se compreenda um único corpo com membros diferentes ${ }^{56}$. Cada membro tem a sua particularidade e função, portanto, não é conveniente que se ampute do corpo. Não se pode deixar com que as diferenças separem os cristãos daquilo que lhes é comum.

\begin{abstract}
Sendo pois a eucaristia o ponto central da vida da Igreja, é natural que tenha constituído também uma das matérias mais destacadas do diálogo ecumênico. Como em outros campos dogmáticos, também em relação a eucaristia não é possível ignorar as diferenças que nos separam dos irmãos de outras confissões cristãs, pois aí radicam os obstáculos que impedem uma intercomunhão plena. Mas também é necessário tomar conhecimento das convergências e do caminho percorrido em direção à unidade. (CNBB. 2006, p.748 $)^{57}$
\end{abstract}

As divergências entre católicos e luteranos sobre a eucaristia são pequenas, porém são essenciais para que a falsa moral cristã se prolifere e os coloque em divisão. Mas, diante da moral fundamental cristã, a burocracia é rompida pela força do amor que traz a união.

\title{
4 CONSIDERAÇÕES FINAIS
}

Conclui, portanto, que as barreiras existentes entre luteranos e luteranos, e luteranos e católicos em torno da mesa do Senhor são reflexos de uma moral ainda pautada na casuística e, portanto, vedada da compreensão da moral fundamental que aponta para a revelação crística do amor.

É notável que pelos grandes avanços já obtidos pela CILC, haja de fato a realização da Hospitalidade Eucarística entre católicos e luteranos. Os grandes esforços realizados pela $\mathrm{CNBB}^{58}$ junto com a IECLB é um indício de que o Brasil possa ser o precursor desse passo importante na realização do Reino.

Considerando os objetivos propostos acerca do tema eucarístico, o presente trabalho de forma sintética repensou por meio da moral cristã as restrições impostas para a participação da mesa eucarística, bem como buscou compreender o pensamento de Lutero sobre a Eucaristia, provocando assim as igrejas luteranas pertencentes aos Concílio Internacional Luterano - ILC e ao sínodo de Wisconsin a removerem o véu da divisão no templo e abrirem-se na comunhão com os demais luteranos, sobretudo com os irmãos pertencentes à Confederação Internacional Luterana.

Acredita-se que, por meio deste artigo, mais um passo importantíssimo foi dado ao propor a presente provocação do encontro eucarístico entre católicos e luteranos.

${ }^{56}$ Cf. 1 Cor. $12,12$.

57 CNBB. "Guia Ecumênico" In: LELO, Antonio Francisco. Eucaristia: Teologia e celebração. São Paulo: Paulinas, 2006.

${ }^{58}$ Conferência Nacional dos Bispos do Brasil. 


\section{REFERÊNCIAS}

.Seminário sobre Hospitalidade Eucarística. Disponível em

<http://www.luteranos.com.br/conteudo/hospitalidade-eucaristica-1>. Acesso e: 20 set. 2018.

BÍBLIA DE JERUSALÉM. São Paulo: Paulus, 2002.

BROUARD, Maurice. Eucharistia: Enciclopédia da eucaristia. $2^{\underline{a} e d . ~ S a ̃ o ~ P a u l o: ~}$

Paulus,2007.

BULTMANN, Rudolf. Teologia do Novo Testamento. São Paulo: Academia Cristã, 2008.

BUSS, Paulo Wille. Comunhão e separação no altar do Senhor: $2^{\circ}$ simpósio internacional de Lutero. Porto Alegre: Concórdia, 2009.

COMISSÃO MISTA NACIONAL CATÓLICO-LUTERANA. A ceia do Senhor. Brasília: CNBB, maio 1978. (Comunicado mensal, n. 308).

COMISSÃO MISTA NACIONAL CATÓLICO-LUTERANA. Relatório de Malta. São Leopoldo: Sinodal, 1974.

CONCÍLIO VATICANO II, 1962-1965. Compêndio do Vaticano II: constituições, decretos, declarações. 18. ed. Petrópolis: Vozes, 1986. 743 p.

DIDAQUÉ. O catecismo dos primeiros cristãos para as comunidades de hoje. 16ª̂ed. São Paulo: Paulus, 2009

GIRAUDO, Cesare. Num só corpo: Tratado mistagógico sobre a eucaristia. São Paulo: Edições Loyola 2003

LACOSTE, Jean-Yves. Dicionário crítico de teologia. $2^{\underline{a}}$ ed. São Paulo: Edições Loyola: Paulinas, 2014.

LELO, Antonio Francisco. Eucaristia: Teologia e celebração. São Paulo: Paulinas, 2006.

LIVRO DE CONCÓRDIA. As confissões da Igreja Evangélica Luterana. $7^{a} e d$. São Leopoldo: Sinodal; Canoas: Ulbra; Porto Alegre: Concórdia, 2016.

LUTERO, Martinho. Obras Selecionadas: Debates e Controvérsias, II. São Leopoldo: Sinodal; Canoas: Ulbra; Porto Alegre: Concórdia, 1993.

LUTERO, Martinho. Obras selecionadas: Os primórdios escritos de 1517-1519. 3aed. São Leopoldo: Sinodal; Canoas: Ulbra; Porto Alegre: Concórdia, 2016.

MUELLER, John Theodore. Dogmática cristã: Um manual sistemático dos ensinos bíblicos. 4ㄹed. Porto Alegre: Concórdia, 2004.

ROCHA, Claudio Oliveira; Rocha, Alessandro Rodrigues. Ecumenismo e Reforma. São Paulo: Paulinas, 2017.

VIDAL, Marciano. Nova moral fundamental: O lar teológico da Ética. Aparecida: Editora Santuário; São Paulo: Paulinas,2003. 